\title{
In vitro inhibition of Plasmodium falciparum by substances isolated from Amazonian antimalarial plants
}

\author{
Valter F de Andrade-Neto, Adrian M Pohlit*/+ , Ana Cristina S Pinto*/***, \\ Ellen Cristina C Silva*/***, Karla L Nogueira*/****, Márcia RS Melo*/**, \\ Marycleuma C Henrique*/***, Rodrigo CN Amorim*/***, Luis Francisco R Silva**/, \\ Mônica RF Costa**, Rita CS Nunomura*, Sergio M Nunomura*, Wilson D Alecrim**, \\ M das Graças C Alecrim**/*****, F Célio M Chaves $* * * * * *$, Pedro Paulo R Vieira ${ }^{* * / * * * * * * *}$
}

\begin{abstract}
Laboratório de Biologia da Malária e Toxoplasmose, Departamento de Microbiologia e Parasitologia, Universidade Federal do Rio Grande do Norte, Natal, RN, Brasil *Laboratório de Princípios Ativos da Amazônia, Coordenação de Pesquisas em Produtos Naturais, Instituto Nacional de Pesquisas da Amazônia, Av. André Araújo 2936, 69060-001 Manaus, AM, Brasil **Laboratório da Gerência de Malária, Fundação de Medicina Tropical do Amazonas, Manaus, AM, Brasil ***Universidade Federal do Amazonas,

Campus Universitário, Manaus, AM, Brasil ****Centro Federal de Educação Tecnológica do Amazonas, Manaus, AM, Brasil *****Centro Universitário Nilton Lins, Manaus, AM, Brasil ******Embrapa Amazonia Ocidental, Manaus, AM, Brasil *******Universidade Estadual do Amazonas, Manaus, AM, Brasil
\end{abstract}

In the present study, a quassinoid, neosergeolide, isolated from the roots and stems of Picrolemma sprucei (Simaroubaceae), the indole alkaloids ellipticine and aspidocarpine, isolated from the bark of Aspidosperma vargasii and A. desmanthum (Apocynaceae), respectively, and 4-nerolidylcatechol, isolated from the roots of Pothomorphe peltata (Piperaceae), all presented significant in vitro inhibition (more active than quinine and chloroquine) of the multi-drug resistant K1 strain of Plasmodium falciparum. Neosergeolide presented activity in the nanomolar range. This is the first report on the antimalarial activity of these known, natural compounds. This is also the first report on the isolation of aspidocarpine from A. desmanthum. These compounds are good candidates for pre-clinical tests as novel lead structures with the aim of finding new antimalarial prototypes and lend support to the traditional use of the plants from which these compounds are derived.

Key words: neosergeolide - ellipticine - aspidocarpine - 4-nerolidylcatechol - Pothomorphe peltata - Picrolemma sprucei Aspidosperma spp.

Malaria is the main cause of economic loss and high morbidity in the world today and continues to be endemic to tropical regions such as the Amazon. In the Brazilian Amazon, 1.6 million positive plates (thick smears) in a total of 8 million diagnostic tests for malaria were registered from January 2004 to February 2007 (Ministério da Saúde, Sivep-Malaria 2007). The lack of an effective vaccine and the increasing expansion of strains of Plasmodium falciparum presenting resistance towards commonly used, low-cost antimalarials make control of this disease difficult (Olliaro \& Bloland 2001, Wellens \& Plowe 2001, Vieira et al. 2001, 2004, Gonzales et al. 2003, Alecrim et al. 2006). As a result, the World Health Organization (WHO 1978, 1995) has been promoting research on natural product based drugs for treatment of disease and many plant species have been evaluated for antimalarial activity (Weniger et al. 2004). In these studies, emphasis has been on the discovery of lead com-

Financial support: CNPq/PPG-7 563892/2005-6 and 557106/ 2005-2, CNPq/PNOPG 520354/1999-0 and 550260/2001-3, Bioamazonia-Basa-Fepad and Fapeam (PIPT 6/2003, CBAUfam 1577/2005, Pinfra 1928/2005)

+Corresponding author: ampohlit@inpa.gov.br

Received 20 February 2007

Accepted 15 May 2007 pounds for drug development (Gundidza \& Chinyanganya 1999). The rational search for active substances in medicinal plants is a very promising and cost-effective strategy for antimalarial drug discovery. This approach benefits from the accumulated knowledge of the curing capacity of plants possessed by inhabitants of malaria endemic regions and permits the extensive evaluation of natural products derived from these sources (Campbell et al. 1997, 1998, 2000, Carvalho \& Krettli 1991, Carvalho et al. 1991, Brandão et al. 1992, 1997, Krettli et al. 2001, Andrade-Neto et al. 2004a,b).

This triage of useful and effective plants is at the heart of traditional medicinal knowledge and is an extremely important source of therapeutic compounds in use today. Important semi-synthetic, low-cost, highly effective antimalarial drugs such as the quinolines (chloroquine, mefloquine, primaquine, etc.) and artemisinin derivatives (sodium artesunate, arteether, artemether, etc.) owe their initial discovery to the isolation and structural identification of antimalarial natural products (quinine and artemisinin, respectively) from traditionally used antimalarial plant species (Cinchona spp. by Amerindians in Peru and Artemisia annua in China, respectively) (Rosenthal 2003). Recent studies on traditionally used antimalarial remedies have revealed plants which produce indole and isoquinoline alkaloids, sesqui-, di- and triterpenes, flavonoids and other substances presenting proven in vitro activity against P. falciparum (Frederich et al. 1999, Phillipson 1999, Muhammad et al. 2004). 
Brazilian flora, especially the vast Amazon forest, is a large, mainly unexplored source of molecules with pharmacological potential. Some examples of substances derived from plants used by Brazilian indians are pilocarpine, extracted from the leaves of jaborandi (Pilocarpus jaborandi), emetine, obtained from the roots of ipeca (Cephaelis ipecacuanha), guaraná seeds ( $\mathrm{Pa}$ ullinia cupana), rich in caffeine, used as stimulant, and curares, extracted from the leaves of Chondondendron spp., used in anesthetic techniques.

Despite the richness of our flora, the role of Brazil in the global production of drugs has been that of a mere supplier of starting materials for international industry. This industry has grown steadily in recent years and is now estimated at US\$ 22 billion each year in phytotherapeutic agents and plant-derived pharmaceuticals (Pinto et al. 2002). However, research in Brazil on chemical, biochemical, and genetic resources must be intensified. Also, academy-industry partnerships must increase in number and must also be accompanied by flexible financing from private and public sectors. Through these and other measures, the identification of bioactive compounds can in principle be optimized, leading to greater profits from the commercialization of plant materials and also lead to a greater degree of sovereignty over our biodiversity.

Research on new antimalarials from natural products involves coordinated scientific effort on the part of different professionals. These professionals generally represent distinct academic disciplines, most importantly, botany, natural product, and synthetic chemistry, pharmacology, parasitology, and molecular biology. Groups with these characteristics can in the short and long run produce sound knowledge of the chemical, pharmacological, and biological diversity. Based on scientifically sound facts, the most promising agents for further clinical and industrial development can be identified.

In this work, the pharmacological potential of several substances isolated from traditionally used antimalarial plants was evaluated through screening for in vitro inhibition of human malaria parasite species $P$. falciparum. The ultimate goal of this work is to identify new classes of antimalarial substance which may serve as prototypes for the development of drug leads having novel mechanisms of action.

\section{MATERIALS AND METHODS}

Plant material, extraction, and chemical constituent isolation - The plants from which the substances under study were isolated are traditionally used for the treatment of malaria and fever in the Amazon region and are known to locals as caferana (Picrolemma sprucei Hook.f., Simaroubaceae), amargoso, araracanga (Aspidoperma desmanthum Benth. ex Müll. Arg., Apocynaceae), amarelão (Aspidosperma vargasii A. DC.), and caapeba-do-norte (Pothomorphe peltata L., Piperaceae). All plant materials were collected in the state of Amazonas in the locations specified below. Voucher specimens are deposited at the Instituto Nacional de Pesquisas da Amazonia and Universidade Federal do Amazonas Herbariums. Plants were dried in the shade or laboratory and milled prior to extraction. Structural elucidation of isolated compounds was performed by analysis of 1-D / 2-D NMR, mass, infrared and ultraviolet spectral data and comparison to spectral data available in the literature.

Isolation of 4-nerolidylcatechol (1) from P. peltata - Caapeba-do-norte was cultivated at Embrapa Amazonia Ocidental (Manaus) and harvested. Roots $(150 \mathrm{~g})$ were extracted with a $1: 1$ mixture of $\mathrm{CHCl}_{3} / \mathrm{EtOH}(3 \times 150$ $\mathrm{ml} ; 15 \mathrm{~min}$ each) in an ultrasound bath. After total evaporation, the extract $(19.5 \mathrm{~g} ; 13 \%)$ was chromatographed on silica gel using a 9:1 mixture of $\mathrm{CHCl}_{3} / \mathrm{EtOH}$ 9:1 which yielded pure $1(8.6 \mathrm{~g}, 44.1 \% \mathrm{w} / \mathrm{w}$ based on extract, $5.7 \%$ based on dry weight of plant.

Isolation of neosergeolide (2) from P. sprucei Caferana was collected in the town of Silves. Roots and stems $(6.5 \mathrm{~kg})$ were degreased with hexanes in a soxhlet apparatus then repeatedly extracted with water using the same equipment. Continuous liquid-liquid extraction of the resulting concentrated $\mathrm{H}_{2} \mathrm{O}$ extract with $\mathrm{CHCl}_{3}$ was then performed. The procedure described up to this point was essentially that described by Moretti et al. (1982) for the isolation of other quassinoids from this plant. We developed a method which obviates the need for a chromatography step. The concentrated chloroform extracts $(35.1 \mathrm{~g})$ were dissolved in a minimum of hot water and acetone (2:1). The resultant precipitate was fractionally recrystallized to give pure neosergeolide (2) ( $685.4 \mathrm{mg}, 0.011 \%$ based on dry weight of plant).

Isolation of ellipticine (3) from A. vargasii - Amarelão was collected at Inpa's Adolpho Ducke Reserve in Manaus. Bark $(1.30 \mathrm{~kg})$ was macerated in $\mathrm{EtOH} / 1 \%$ $\mathrm{NH}_{4} \mathrm{OH}$ (aq.). After filtration, evaporation of solvents and freeze-drying, extract (56 g) was obtained which was dissolved in ethyl acetate and partitioned with dilute, aqueous hydrochloric acid. The aqueous layer was basified to $\mathrm{pH} 8$ and then extracted with chloroform. After separation of layers and total evaporation, an alkaloid-rich fraction was obtained $(8.02 \mathrm{~g})$. A portion $(7 \mathrm{~g})$ of this fraction was sequentially chromatographed on silica (CC, then TLC) using different eluentes to yield ellipticine $(3,68.2 \mathrm{mg}$, $0.0052 \%$ based on dry weight of plant).

Isolation of aspidocarpine (4) from A. desmanthum - Collection and extraction of amargoso (araracanga), as well as isolation and purification of 4 , was essentially the same as described above for 3 , wherein bark $(1.2 \mathrm{~kg})$ yielded ethanol extract $(35 \mathrm{~g})$ which was partitioned and yielded an alkaloid rich $\mathrm{pH} 8$ fraction (1.45 g). Sequential normal-phase chromatography on a portion $(1.40 \mathrm{~g})$ of this fraction yielded aspidocarpine $(68.5 \mathrm{mg}, 0.0057 \%$ based on dry weight of plant).

Parasite culture and in vitro antimalarial tests Chloroquine, pyrimethamine, and cycloguanil resistant P. falciparum strain K1 was acquired from MR4 (Malaria Research and Reference Reagent Resource Center, Manassas, Virginia, US) and was used in the in vitro tests. Parasites were maintained in continuous culture in A+ human erythrocytes, using RPMI medium supplemented with $10 \%$ human serum, as described by Trager and Jensen 
(1976). The antiparasitic effect of the compounds was measured by growth inhibition percentage as described by Carvalho and Krettli (1991). Briefly, trophozoitestages in sorbitol-synchronized blood (Lambros \& Vanderberg 1979) were cultured at 1-2\% parasitaemia and $2.5 \%$ hematocrit and then incubated with the plant extracts or isolated compounds (maximum $1 \mathrm{mg} / \mathrm{ml}$ in serial dilutions), diluted with $0.02 \%$ final concentration of DMSO in culture medium (RPMI 1640) for a total of $48 \mathrm{~h}$ at $37^{\circ} \mathrm{C}$. A positive control with reference antimalarial drug (chloroquine and quinine) in standard concentrations (Rieckmann et al. 1978; WHO 2001) was used in each experiment. The stock solutions were further diluted in complete medium (RPMI 1640 plus 10\% human serum) to each of the used concentrations ( 0.0001 up to 100 $\mu \mathrm{g} / \mathrm{ml}$ in seven dilutions). The half-maximal inhibitory $\left(\mathrm{IC}_{50}\right)$ responses as compared to the drug-free controls were estimated by interpolation using Microcal Origin ${ }^{\circledR}$ software. Each duplicate experiment was repeated three times and blood smears were read blind.

Statistical analysis - The data of in vitro antimalarial tests were analyzed with the Biostat 1.0 MCT-CNPq software package using Anova and Student's $t$-test.

\section{RESULTS}

The results of the in vitro tests with compounds obtained from plant extracts against multidrug-resistant $P$. falciparum $\mathrm{K} 1$ strain are presented in the Table. The $\mathrm{IC}_{50}$ of compounds ranged from $2.0 \mathrm{nM}$ to $0.67 \mu \mathrm{M}$. Neosergeolide (2), a known quassinoid which has previously been isolated from Picrolemma sprucei but for which no data on antimalarial activity has been previously reported, showed significantly higher activity $\left(\mathrm{IC}_{50}=2.0\right.$ $\mathrm{nM}$ ) than did the other compounds tested. Fig. 1 illustrates the dose-response curve for this quassinoid showing a tendency of standard curve; this analysis was performed for all tested compounds. Ellipticine and aspidocarpine are known indole alkaloids for which antimalarial activity has not apparently been previously described. Both presented significant inhibition of parasite growth $\left(\mathrm{IC}_{50}=73\right.$ and $19 \mathrm{nM}$, respectively). 4Nerolidylcatechol, a metabolite found in Pothomorphe peltata for which no data is available as to antimalarial<smiles>C=CC(C)(CC/C=C(\C)CCC=C(C)C)c1ccc(O)c(O)c1</smiles>

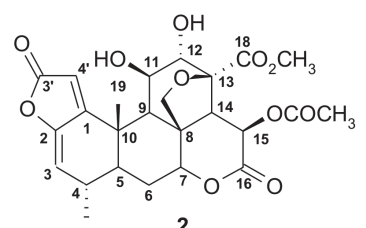<smiles>Cc1c2ccncc2c(C)c2c1[nH]c1ccccc12</smiles><smiles>CCC12CCCN3CCC4(c5ccc(OC)c(O)c5N(OC)C4CC1)C32</smiles>

Fig. 1: structures of isolated antimalarial compounds.

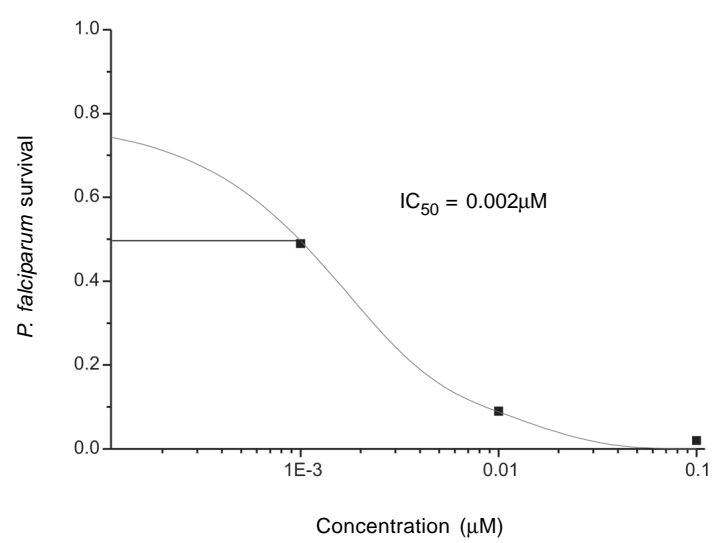

Fig. 2: illustrative dose-response curve for multi-drug resistant Plasmodium falciparum $\mathrm{K} 1$ strain in the presence of different concentrations of the quassinoid neosergeolide (2) tested with $\mathrm{IC}_{50}$ value in representative experiment; confidence interval $(95 \% \mathrm{CI})=0.00-0.01$. Statistical analysis among additional assays showed: standard error $=0.0007 ; p=0.10$.

activity, presented good parasite inhibition $\left(\mathrm{IC}_{50}=0.67\right.$ $\mu \mathrm{M})$. The in vitro sensitivity of the $P$. falciparum strain to the compounds tested was similar and reproducible in assays in duplicate on separate occasions.

\section{TABLE}

The half-maximal inhibitory concentrations $\left(\mathrm{IC}_{50}\right)$ of isolated substances from Pothomorphe peltata, Picrolemma sprucei, Aspidosperma vargasii, and A. desmanthum towards Plasmodium falciparum (K1 strain)

\begin{tabular}{|c|c|c|c|c|}
\hline \multirow[b]{2}{*}{ Compound name } & \multirow[b]{2}{*}{ Structural class } & \multirow[b]{2}{*}{ Plant species/source } & \multicolumn{2}{|c|}{ Mean $\mathrm{IC}_{50}$ values $^{a}$} \\
\hline & & & $\mu \mathrm{g} / \mathrm{ml}$ & $\mu \mathrm{M}$ \\
\hline Neosergeolide & Quassionoid/terpenoid & Picrolemma sprucei & 0.001 & 0.002 \\
\hline Ellipticine & Indole alkaloid & Aspidosperma vargasii & 0.018 & 0.073 \\
\hline Aspidocarpine & Indole alkaloid & Aspidosperma desmanthum & 0.007 & 0.019 \\
\hline 4-Nerolidylcatechol & Phenylpropanoid/terpenoid & Pothomorphe peltata & 0.21 & 0.67 \\
\hline Chloroquine diphosphate salt & Quinoline & Synthetic commercial standard & 0.46 & 0.89 \\
\hline Quinine salt & Quinoline alkaloid & Natural commercial standard & 0.004 & 0.012 \\
\hline
\end{tabular}

$a$ : mean values in representative assay. All experiments were performed in duplicate. 


\section{DISCUSSION}

Plants of the family Simaroubaceae are widely used in traditional medicine for the treatment of malaria, cancer, dysentery, and other diseases in countries around the world (Okano et al. 1990, Muhammad et al. 2004). Quassinoids are a group of degraded triterpenes found in the family Simaroubaceae, that show many biological activities such as antitumor (Fukamiya et al. 2005), antifeedant (Daido et al. 1995), phytotoxic (De Feo et al. 2003), antiviral (Apers et al. 2002), and antihelmintic (Nunomura et al. 2006). The antimalarial activity of some quassinoids like brusatol, glaucarubinone and quassin has been demonstrated previously (Wright 2005).

An ethnopharmacological study in French Guyana showed that $P$. sprucei root, stem and bark alcohol extract is used in local traditional medicine as a curative treatment for malaria in association with Geissospermum spp. (Apocynaceae) and Quassia amara (Simaroubaceae) or modern drugs (Vigneron et al. 2005). In a subsequent study, Bertani et al. (2005) demonstrated that $P$. sprucei water extract can inhibit hemozoin formation. In vitro assays demonstrated the antimalarial activity of this extract against the chloroquine resistant $P$. falciparum strain W2. Sergeolide and isobrucein B are quassinoids which have been isolated previously from $P$. sprucei and exhibit high antiplasmodial activity. Against chloroquine-sensitive FUP strain, sergeolide exhibited an $\mathrm{IC}_{50}$ which was five times less than that of isobrucein $\mathrm{B}$ and three times less than the that of chloroquine in the same strain. In vivo assays demonstrated that sergeolide was capable of inhibiting $P$. berghei strain NK65 with an $\mathrm{ED}_{50}$ of $0.2 \mathrm{mg} / \mathrm{kg} / \mathrm{day}$, five times less than chloroquine (Fandeur et al. 1985).

Our data show that the quassinoid isolated from the roots and stems of the P. sprucei was more active than quinine and chloroquine; with activities in the micromolar ranges comparable to recently reported results. Several quassinoids are known to inhibit the growth of $P$. falciparum in culture at nanomolar concentrations (Kuo et al. 2004). The quassinoids orinocinolide and simalikalactone D, isolated from the root bark of Simaba orinocensis were found to be potent in vitro against $P$. falciparum clones D6 and W2 (Muhammad et al. 2004). Research has also revealed quassinoids which are 4 and 12 times more active in vivo (via oral) against rodent malaria parasite (Phillipson et al. 1993) than chloroquine and artemisinin, respectively (Kim et al. 2000). Despite these antimalarial activities, quassinoids usually present toxicity due principally to protein synthesis inhibition and it is likely that parasite and host cell ribosomes are too similar to allow for the development of selective inhibitors (Wright 2005). Some structural requirements, like an $\alpha, \beta$-unsaturated ketone in the A ring, an epoxymethylene bridge in the $\mathrm{C}$ ring and an ester function in C-15 are considered very important for the antimalarial activity presented by quassinoids (Phillipson et al. 1986, Amorim \& Pohlit 2006).

Two morphologically similar species of Pothomorphe, namely $P$. peltata and P. umbellata, occur widely in Brazil. Both are known by the popular name caapeba, among other names, and are used in traditional medicine for the treatment of malaria. Both plants produce the secondary metabolite of mixed terpene and phenylpropanoid biosynthetic origin, 4-nerolidylca-techol, which was evaluated in the present study. Qualitative tests have shown the presence of this compound in the root, leaf and inflorescences of $P$. peltata and literature would seem to suggest a similar distribution in P. umbellata (Pinto 2002).

Several studies on the in vitro and in vivo antimalarial activities of $P$. umbellata and P. peltata have been reported. Amorim et al. (1986) evaluated the ethanol extracts of $P$. umbellata (leaves) and $P$. peltata (whole plant) against $P$. berghei in vivo. Reductions in parasitemia of 66, 55, and 28\% were observed for the $P$. umbellata extract, whereas no activity was observed for P. peltata extract. In a similar study, Amorim et al. (1988) evaluated leaf ethanol extracts of these same species by subcutaneous and oral administration and found that $P$. umbellata leaf extract significantly reduced blood parasite levels at different doses whereas $P$. peltata leaf extract was inactive at $500 \mathrm{mg} / \mathrm{kg}$ in both tests. On the other hand, Adami (1995) evaluated P. peltata and P. umbellata leaf hexane and methanol extracts in vivo through oral and subcutaneous administration in $P$. berghei infected mice and found that these extracts were inactive against blood forms of P. berghei. These results lead Ferreirada-Cruz et al. (2000) to conclude that the oral or subcutaneous administration of plant extracts in Plasmodium berghei infected rats was not effective at detecting the antimalarial activity of these plants.

Sala-Neto et al. (1992) tested the in vivo and in vitro antimalarial activity of $P$. peltata leaf, root and stem water extract using a new method. Briefly, this method involved oral administration in adult rats via gavage tube $(6 \times 6 \mathrm{ml})$ for 2 days. After this period of treatment, the rats were bled and blood sera were tested in vitro in microcultures of $P$. falciparum using tritium-labeled hypoxanthine incorporation for parasite quantification. In vitro $P$. falciparum inhibition (49\%) was observed for serum obtained from rats inoculated with $P$. peltata water extract versus controls. From the results of this and other experiments, differences in $P$. berghei and $P$. falciparum blood-stage biology might be thought to be responsible for the lack of in vivo activity observed for Pothomorphe spp. extracts by some authors.

Adami (1995) also evaluated P. peltata and P. umbellata leaf hexane and methanol extracts in vitro in human malaria parasite species $P$. falciparum. The methanol extracts of both species presented greater inhibition of $P$. falciparum growth than the hexane extracts. In a more recent study, Atindehou et al. (2004) observed the in vitro antiplasmodial activity of $P$. umbellata leaf ethanol extract $\left(\mathrm{IC}_{50} 3.7 \mu \mathrm{g} / \mathrm{ml}\right)$ in chloroquine and pyrimethamine resistant $P$. falciparum. We obtained a similar result for the alcohol root extract of $P$. peltata in vitro in the $\mathrm{K} 1$ strain of $\mathrm{P}$. falciparum. In preliminary work, 4-nerolidylcatechol (1) was shown to be active against $P$. falciparum in vitro (Pinto 2002).

The screening of natural products provides the chance to discover new molecules of unique structure with high 
activity and selectivity which can be further optimized by semi- or fully synthetic procedures (Holzgrabe \& Bechthold 1999).

Alkaloids are one of the most fascinating classes of natural products, providing many drugs for human use (Phillipson et al. 1993, Kayser et al. 2003). In general, indole alkaloids are a class of compound having a range of biological activities, including antibacterial, trypanocidal, leishmanicidal and anticancer (Sakamoto-Hojo et al. 1988, Delorenzi et al. 2001, Kuo et al. 2004, Ferreira et al. 2006, Tanaka et al. 2006). The antiplasmodial activity of monoterpene indole alkaloids has been investigated (Wright et al. 1994, Iwu et al. 1994). Promising results have been obtained previously by others for aspidospermidine structural analogues isolated from A. pyrifoluim and A. megalocarpon to Nigerian chloroquine-sensitive and a Camaroon chloroquine-resistant (FcM2) strain of $P$. falciparum. In the chloroquine-resistant strain, apidospermine, 10-methoxyaspidospermidina and $\mathrm{N}$-formylaspidospermidine presented, after $24 \mathrm{~h}, \mathrm{IC}_{50}$ of 16.3, 19.5 and, $16.1 \mu \mathrm{M}$, respectively, whereas after $72 \mathrm{~h}, \mathrm{IC}_{50}$ were $3.8,3.2$, and $5.6 \mu \mathrm{M}$, respectively. In the chloroquine-sensitive strain, after 24 $\mathrm{h}, \mathrm{IC}_{50}$ were $11.0,13.1$, and $22.0 \mu \mathrm{M}$, respectively, and after $72 \mathrm{~h}, 4.6,5.1$, and $5.9 \mu \mathrm{M}$, respectively (MitaineOffer et al. 2002). Here, the isolated monoterpene indole alkaloids ellipticine (3) and aspidocarpine (4) were more active. The activities against $\mathrm{K} 1$ strain were of the same order as those observed for the terpeneoidphenylpropanoid compound 4-nerolidylcatechol (1).

Those compounds or chemical groups have already shown potential as new drug leads or may have an impact on future drugs. Further studies should explore these compounds as a prototype for an antimalarial aimed at the $P$. falciparum mult-resistant parasites.

Adaptation of the protocol cited above to highthroughput platforms, as well as implementation of modern indirect methods for the quantification of in vitro parasite growth, such as fluorimetry (Smilkstein et al. 2004) are underway and will be essential for an increase in the scale and dynamism of studies on antimalarial plants, isolated natural substances and their semi-synthetic derivatives, potentializing a process of continuous screening in the near future.

Additionally, stabilization of geographically specific $P$. falciparum populations in continuous in vitro culture is underway and should permit investigations into the real susceptibility profile of these regional parasites to the active substances and plant extracts which present promising inhibitory concentrations. It is our hope that knowledge of this regional profile can be useful for the identification, based on sound experimental evidence, of the most important and effective medicinal plants for development of new and effective antimalarials for local use. Furthermore, simultaneous studies on the macromolecular profiles of these parasites in association with analysis of genetic resistance markers ( $\mathrm{Mu}$ et al. 2007) should contribute to the elucidation of possible mechanisms of resistance of the parasites to the natural products tested as well as aid in the discovery of new targets (and/or new mechanisms of action) for antimalarial chemotherapy.

\section{ACKNOWLEDGEMENTS}

These research activities were performed under the InpaFMTAM general agreement. To Dr Antoniana U Krettli (CPqRR/ Fiocruz) for contacts and support which lead to the present collaboration. To Michele Rodrigues, Wallderlice Salgado, and Adriana Enriconi for technical support provided during the in vitro culturing and antimalarial testing procedures. The following authors acknowledge the scholarships received from the indicated agencies: VFAN (MCT/INPA/PCI), RCNA and MRSM (CNPq 142115/06-1 and 384136/06-0, respectively), MCH and ECCS (Capes), KLN and ACSP (Fapeam).

\section{REFERENCES}

Adami YL 1995. Estudo in Vivo e in Vitro da Potencial Atividade Antimalárica de Pothomorphe peltata $e$ Pothomorphe umbellata (L.) Miq., MSc Thesis, Instituto Oswaldo CruzFiocruz, Rio de Janeiro, 102 pp.

Alecrim MG, de Lacerda MV, Mourão MP, Alecrim WD, Padilha A, Cardoso B, Boulos M 2006. First Brazilian experience with the use of artemether-lumefantrine (Coartem) a fixeddosed ACT combination. Am J Trop Med Hyg 75: 187.

Amorim CZ, Flores CA, Gomes BE, Marques AD, Cordeiro RSB 1988. Screening for antimalarial activity in the genus Pothomorphe. J Ethnopharmacol 24: 101-106.

Amorim CZ, Gomes BE, Flores CA, Cordeiro RSB 1986. Antimalarial activity screening from plants of the genus Pothomorphe. Braz J Med Biol Res 19: 569A.

Amorim RCN, Pohlit AM 2006. Picrolemma sprucei Hook. f.: uso tradicional, princípios ativos e seus derivados semi-sintéticos, exploração comercial e econômica. Fitos 2: 10-14.

Andrade-Neto VF, Goulart MOF, Silva Filho JF, da Silva MT, Pinto MCFR, Pinto AV, Zalis MG, Carvalho LH, Krettli AU 2004a. Antimalarial activity of phenazines from lapachol, $\beta$ lapachone and its derivatives against Plasmodium falciparum in vitro and Plasmodium berghei in vivo. Bioorg Med Chem Letters 14: 1145-1149.

Andrade-Neto VF, Brandão MGL, Oliveira FQ, Casali VWD, Njaine B, Zalis MG, Oliveira LA, Krettli AU 2004b. Antimalarial activity of Bidens pilosa L. (Asteraceae) ethanol extracts from wild plants collected in various localities or plants cultivated in humus soil. Phytother Res 18: 634-639.

Apers S, Cimanga K, Berghe DV, Meenen EV, Longanga AO, Foriers A, Vlietinck A, Peters L 2002. Antiviral activity of simalikalactone D, a quassinoid from Quassia africana. Planta Med 68: 20-24.

Atindehou KK, Schmid C, Brun R, Kone MW, Traore D 2004. Antitrypanosomal and antiplasmodial activity of medicinal plants from Cote d'Ivoire. J Ethnopharmacol 90: 221-227.

Bertani S, Bourdy G, Landau I, Robinson JC, Esterre P, Deharo E 2005. Evaluation of French Guiana traditional antimalarial remedies. J Ethnopharmacol 98: 45-54.

Brandão MGL, Grandi TSM, Rocha EMM, Sawyer DR, Krettli AU 1992. Survey of medicinal plants used as antimalarials in the Amazon. J Ethnopharmacol 36: 175-182.

Brandão MGL, Krettli AU, Soares LSR, Nery CGC, Marinuzzi HC 1997. Antimalarial activity of extracts and fractions from Bidens pilosa and other Bidens species (Asteraceae) correlated with the presence of acetylene and flavonoid compounds. J Ethnopharmacol 57: 131-138.

Campbell WE, Gramon DW, Smith P, Abrahams M, Purves TD 
1997. Composition and antimalarial activity of essential oil of Tetradenia riparia. Planta Med 63: 270-272.

Campbell WE, Nair JJ, Gramon DW, Bastida J, Codina C, Viladomat F, Smith PJ, Albrecht CF 1998. Cytotoxic and antimalarial alkaloids from Brunsvigia littoralis. Planta Med 64: 91-93.

Campbell WE, Nair JJ, Gramon DW, Codina C, Bastida J, Viladomat F, Smith PJ, Albrecht CF 2000. Cytotoxic and antimalarial alkaloids from Brunsvigia radulosa. Phytochem 53: $587-591$.

Carvalho LH, Krettli AU 1991. Antimalarial chemotherapy with natural products and chemically defined molecules. Mem Inst Oswaldo Cruz 86 (Suppl. II): 181-184.

Carvalho LH, Brandão MGL, Santos-Filho D, Lopes JLC, Krettli AU 1991. Antimalarial activity of crude extracts from Brazilian plants in vivo in Plasmodium berghei infected mice and in vitro against Plasmodium falciparum in culture. Braz J Med Biol Res 24: 1113-1123.

Daido M, Ohno N, Imamura K, Fukamiya N, Hatakoshi M, Yamazaki H, Tagahara K, Lee K,Okano M 1995. Antifeedant and insecticidal activity of quassinoids against the diamondblack moth (Plutela xylostella) and structure-activity relationships. Biosci Biotech Biochem 59: 974-979.

Delorenzi JC, Attias M, Gattass CR, Andrade M, Rezende C, Pinto AC, Henriques AT, Bou-Habib DC, Saraiva EM 2001. Antileishmanial activity of an indole alkaloid from Peschiera australis. Antimicrob Agents Chemother 45: 1349-1354.

De Feo V, Martino L, Quaranta E, Pizza C 2003. Isolation of phytotoxic compounds from tee-of heaven (Ailanthus altissima Swingle). J Agric Food Chem 51: 1177-1180.

Fandeur T, Moretti C, Polonsky J 1985. In vitro and in vivo assessment of the antimalarial activity of sergeolide. Planta Medica 51: 20-23.

Ferreira ME, Nakayama H, de Arias AR, Schinini A, de Bilbao NV, Serna E, Lagoutte D, Soriano-Agaton F, Poupon E, Hocquemiller R, Fournet A 2006. Effects of canthin-6-one alkaloids from Zanthoxylum chiloperone on Trypanosoma cruzi-infected mice. J Ethnopharmacol 109: 258-263.

Ferreira-da-Cruz MF, Adami YL, Espinola-Mendes EC 2000. The intraperitoneal Plasmodium berghei-Pasteur infection of Swiss mice is not a system that is able to detect the antiplasmodial activity in the Pothomophe plant extract that are used as antimalarials in Brazilian endemic areas. Exp Parasitol 94: 243-247.

Frederich M, Hayette M-P, Tits M, De Mol P, Angenot L 1999. In vitro activities of Strychnos alkaloids and extracts against Plasmodium falciparum. Antimicrob Agents Chemother 43: 2328-2331.

Fukamiya N, Lee K, Muhammad I, Murakami C, Okano M, Harvey I, Pelletier J 2005. Struture-activity relationships of quassinoids for eukaryotic protein synthesis. Cancer Letters 220: 37-48.

Gonzalez IJ, Varela RE, Murillo C, Ferro BE, Salas J, Giraldo LE, Zalis MG, Saravia NG 2003. Polymorphisms in cg2 and pfcrt genes and resistance to chloroquine and other antimalarials in vitro in Plasmodium falciparum isolates from Colombia. Trans R Soc Trop Med Hyg 97: 318-324.

Gundidza RW, Chinyanganya FW 1999. Natural products research in Zimbabwe. Proceedings of symposium on African medici- nal and indigenous food plants. University of Swaziland, Kwaluseni, Swaziland, p. 60-72.

Holzgrabe U, Bechthold A 1999. Paradigmenwechsel in der Entwicklung antiinfectiver chemotherapeutika. Chemother $J$ 8: 69-78.

Iwu MM, Klayman DL, Jackson JE, Tally JD, Andersen SL 1994. Alkaloids of Picralima nitida used for treatment of protozoal diseases. The Secretary of the Army USA Patent No. 5,290,553, $21 \mathrm{pp}$.

Kayser O, Kiderlen AF, Croft SL 2003. Natural products as antiparasitic drugs. Parasitol Res 90: S55-S62.

Kim H, Shibata Y, Ko N, Ikemoto N, Ishizuka Y, Murakami N, Sugimoto M, Kobayashi M, Wataya Y 2000. Potent in vitro antimalarial activity of 3,15-di- $O$-acetylbruceolide against Plasmodium berghei infection in mice. Parasitol Internatl 48: 271-274.

Krettli AU, Andrade-Neto VF, Brandão MGL, Ferrari WMS 2001. Searching new antimalarials from plants used to treat fever and malaria or plants randomly select: a review. Mem Inst Oswaldo Cruz 96: 1033-1042.

Kuo P-C, Damu AG, Lee K-H, Wu T-S 2004. Cytotoxic and antimalarial constituents from roots of Eurycoma longifolia. Bioorg Med Chem 12: 537-544.

Kuo CC, Hsieh HP, Pan WY, Chen CP, Liou JP, Lee SJ, Chang YL, Chen LT, Chen CT, Chang JY 2004. BPR0L075, a novel synthetic indole compound with anti-mitotic activity in human cancer cells, exerts effective antitumoral activity in vivo. Cancer Res 64: 4621-4628.

Lambros C, Vanderberg JP 1979. Syncronization of Plasmodium falciparum erythrocytic stages in culture. J Parasitol 65: 418-420.

Mitaine-Offer AC, Sauvain M, Valentin A, Callapa J, Mallié M, Zèches Hanrot M 2002. Antiplasmodial activity of Aspidosperma indole alkaloids. Phytomedicine 9: 142-145.

Moretti C, Polonsky J, Vuilhorgne M, Prange T 1982. Isolation and structure of sergeolide, a potent cytotoxic quassinoid from Piclolemma pseudocoffea. Tetrahedron Lett 23: 647-650.

Mu J, Awadalla P, Duan J, McGee KM, Keebler J, Seydel K, McVean GA, Su XZ 2007. Genome-wide variation and identification of vaccine targets in the Plasmodium falciparum genome. Nat Genet 39: 126-130.

Muhammad I, Bedir E, Khan SI, Tekwni BL, Khan IA, Takamatsu S, Pelletier J, Walker LA 2004. A new antimalarial quassinoid from Simaba orinocensis. J Nat Prod 67: 772-777.

Nunomura RCS, Silva ECC, Oliveira DF, Garcia AM, Boeloni JN, Nunomura SM, Pohlit AM 2006. In vitro studies of the anthelmintic activity of Picrolemma sprucei Hook. f. (Simaroubaceae). Acta Amaz 36: 327-330.

Olliaro PL, Bloland PB 2001. Clinical and public health implications of antimalarial drug resistance. In P Rosenthal, Antimalarial Chemotherapy: Mechanisms of Action, Resistance, and New Directions in Drug Discovery, Humana, Totowa, New Jersey, p. 65-83.

Okano M, Fukayima N, Lee NK 1990. Biologically active compounds from Simaroubaceous plants. In Studies of Natural Products Chemistry, Elsevier, Amsterdam, vol. 7, p. 369-404.

Phillipson JD 1999. New drugs from nature - It could be yew. Phytother Res 13: 2-8.

Phillipson JD, O’Neill MJ 1986. Novel antimalarial drugs from plants. Parasitol Today 2: 355-359. 
Phillipson JD, Wright CW, Kirby GC, Warhurst DC 1993. Tropical plants as sources of antiprotozoal agents. In KR Downum, JT Romeo, HA Stafford (eds), Phytochemicals of Tropical Plants, Plenum Press, New York, p. 1-40.

Pinto ACS 2002. Estudo fitoquímico e farmacológico de Pothomorphe peltata, MSc Thesis, Universidade Federal do Amazonas, Manaus.

Pinto AC, Silva DHS, Bolzani VS, Lopes NP, Epifânio RA 2002. Produtos naturais: atualidade, desafios e perspectivas. Quim Nova 25: 45-61.

Rieckmann KH, Sax LJ, Campbell GH, Mrema JE 1978. Drug sensitivity of Plasmodium falciparum. An in vitro microtechinique. Lancet 1: 22-23.

Rosenthal PJ 2003. Antimalarial drug discovery: old and new approaches. J Exp Biology 206: 3735-3744.

Sala-Neto F, Da Silva JS, Pires RO, Nascimento NP, Brenner C, Boubli JP, Tosta CE 1992. Uma nova metodologia para a avaliação da atividade antimalárica de produtos vegetais: aplicação ao estudo de 83 espécies da flora Brasileira. Anais do $2^{\circ}$ Simpósio de Malária. Rev Soc Bras Med Trop 25 (Supl. III): 92.

Sakamoto-Hojo ET, Takahashi CS, Ferrari I, Motidome M 1988. Clastrogenic effect of the plant alkaloid ellipticine on bone marrow cells of wistar rats and on human peripheral blood lymphocytes. Mutat Res 199: 11-19.

Smilkstein M, Sriwilaijaroen N, Kelly JX, Wilairat P, Riscoe M 2004. Simple and inexpensive fluorescence-based technique for high-throughput antimalarial drug screening. Antimicrob Agents Chemother 48:1803-1806.

Tanaka JCA, Silva CC, Dias Filho, BP, Nakamura CV, Oliveira AJB 2006. Antibacterial activity of indole alkaloids from $A s$ pidosperma ramiflorum. Braz J MedBiol Res 39: 387-391.

Trager W, Jensen JB 1976. Human malaria parasites in continuous culture. Science 193: 673-675.

Verpoorte R, Ruigrok CLM, Bearheim SA 1982. Antimicrobial active alkaloids from Aspidosperma marcgravianum. Planta Med 46: 149-152.
Vieira PP, das Gracas Alecrim M, da Silva LH, Gonzalez-Jimenez I, Zalis MG 2001. Analysis of the PfCRT K76T mutation in Plasmodium falciparum isolates from the Amazon region of Brazil. J Infect Dis 183: 1832-1833.

Vieira PP, Ferreira MU, Alecrim MG, Alecrim WD, da Silva LH, Sihuincha MM, Joy DA, Mu J, Su XZ, Zalis MG 2004. pfcrt polymorphism and the spread of chloroquine resistance in Plasmodium falciparum populations across the Amazon Basin. J Infect Dis 190: 417-424.

Vigneron M, Deparis X, Deharo E, Bourdy G 2005. Antimalarial remedies in French Guiana: a knowledge attitudes and practices study. J Ethnopharmacol 98: 351-360.

Wellens TE, Plowe CV 2001. Chloroquine-resistance malaria. J Infec Dis 184: 770-776.

Weniger B, Lagnika L, Vonthron-Sénécheau C, Adjobimey T, Gbenou J, Moudachirou M, Brun R, Anton R, Sanni A 2004. Evaluation ethnobotanically selected Benin medicinal plants for their in vitro antiplasmodial activity. J Ethnopharmacol 90: 279-284.

WHO-World Health Organization 1978 . The promotion and development of traditional medicine. Technical report. Geneve, $622 \mathrm{pp}$.

WHO-World Health Organization 1995. The world health report. Bridging the gaps. Geneve, $118 \mathrm{pp}$.

WHO-World Health Organization 2001. In vitro micro-test (Mark III) for the assessment of the response of Plasmodium falciparum to chloroquine, mefloquine, quinine, amodiaquine, sulfadoxine / pyrimetamine and artemisinin. Division of Control of Tropical Disease. Rev. 2 CTD/MAL/97.20.

Wright CW 2005. Traditional antimalarials and development of novel antimalarial drugs. J Ethnopharmacol 100: 67-71.

Wright CW, Allen D, Cai Y, Chen Z, Phillipson JD, Kirby GC, War-hurst DC, Tits M, Angenot L 1994. Selective antiprotozoal activity of some Strychnos alkaloids. Phytother Res 8: 149-152. 
